\title{
Urgent Surgical Treatment of GIST of Esophago-Gastric Junction in a Patient with Giant Hiatal Hernia
}

\author{
Urgentní chirurgická léčba GIST ezofago-gastrické junkce \\ u pacienta s obrovskou hiátovou kýlou
}

\author{
Romic I. ${ }^{1}$, Pavlek G. ${ }^{1}$, Romic M. ${ }^{2}$, Moric T. ${ }^{1}$, Bajt M. ${ }^{3}$, Puz P. ${ }^{4}$, Grgic D. ${ }^{1}$, Petrovic I. ${ }^{1}$ \\ ' Department of Surgery, University Hospital Centre Zagreb, Croatia \\ ${ }^{2}$ Department of Surgery, University Hospital Sestre milosrdnice, Croatia \\ ${ }^{3}$ Medical School Zagreb, Croatia \\ ${ }^{4}$ General Hospital Koprivnica, Croatia
}

\begin{abstract}
Summary
Gastrointestinal stromal tumors (GISTs), being the most common mesenchymal tumors of the gastrointestinal tract, arise most commonly in stomach (60-70\%) and small intestine (20-25\%) while other sites of origin are rare. In most cases, they are diagnosed accidentally due to their indolent clinical course; however, $10-30 \%$ have malignant potential. Gastric and esophageal GISTs carry a better prognosis than small bowel GISTs of similar size and mitotic rate. Complete surgical resection is the only potentially curative procedure, but despite its success, at least $50 \%$ of patients develop recurrence or metastases. Tyrosine kinase inhibitor imatinib gave positive results in treatment of unresectable, metastatic or recurrent GISTs. We present the case of a 69-year-old woman with a large unresectable GIST of esophago-gastric junction with multiple bilobar liver metastases who underwent an emergent palliative surgery due to diffuse bleeding from the tumor. Twelve months after the surgery, patient is still alive and stable under imatinib therapy with no signs of local recurrence of the disease. This example suggests that patients with locally advanced GISTs with distant metastases may benefit from surgery in terms of prolonged survival and quality of life.
\end{abstract}

Key words

GIST - stomach - hiatal hernia - resection

\section{Souhrn}

Gastrointestinální stromální tumory (GIST), které jsou nejčastějšími mezenchymálními nádory gastrointestinálního traktu, se nejčastěji vyskytují v žaludku (60-70\%) a tenkém střevě (20$25 \%$ ), zatímco jiná místa původu jsou vzácná. $Z$ důvodu indolentního klinického průběhu jsou ve většině př́ípadů diagnostikovány náhodně, $10-30 \%$ však vyjadřuje maligní potenciál. GIST žaludku a jícnu mívají lepší prognózu než GIST tenkého střeva podobné velikosti a rychlosti mitózy. Úplná chirurgická resekce je jediným potenciálně léčebným zákrokem, ale navzdory jejímu úspěchu se u nejméně $50 \%$ pacientů objeví recidiva nebo metastázy. Pozitivní výsledky $\checkmark$ léčbě neresekovatelných, metastatických nebo rekurentních GIST vykazoval inhibitor tyrozinkinázy imatinib. Prezentujeme případ 69leté ženy s velkým neresekovatelným GIST ezofágo-gastrického spojení s mnohočetnými metastázami jaterních bilobarů, která podstoupila paliativní chirurgickou operaci v důsledku difuzního krvácení z nádoru. Dvanáct měsíců po operaci je pacientka stále naživu a stabilní při léčbě imatinibem bez známek lokální recidivy onemocnění. Tento príklad naznačuje, že pacienti s lokálně pokročilými GIST se vzdálenými metastázami mohou mít prospěch z operace z hlediska prodlouženého prežití a kvality života.
The authors declare they have no potential conflicts of interest concerning drugs, products, or services used in the study.

Autor̆i deklarují, že $v$ souvislosti s předmětem studie nemaji žádné komerční zájmy.

The Editorial Board declares that the manuscript met the ICMJE recommendation for biomedical papers.

Redakční rada potvrzuje, že rukopis práce splnil ICMJE kritéria pro publikace zasílané do biomedicínských časopisů.

Ivan Romic, M.D.

Department of Surgery

University Hospital Centre Zagreb

Kišpatićeva ul. 12

10000 Zagreb, Croatia

e-mail: i.romic@gmail.com

Submitted/Obdrženo: 10. 3. 2019

Accepted/Přijato: 14. 5. 2019

doi: 10.14735/amko2019306

Klíčová slova

GIST - žaludek - hiátová hernie - resekce 


\section{Introduction}

Gastrointestinal stromal tumors (GISTs), classified into soft tissue sarcomas according to the National Comprehensive Cancer Network (NCCN) classification, are the most common mesenchymal tumors arising within the wall of the gastrointestinal (GI) tract. GISTs account for $1-3 \%$ of all Gl malignancies. They occur with almost the same frequency in men and women with an incidence of $2-3 / 100000$, usually in the sixth decade of life [1].

They arise from the interstitial cells of Cajal, "pace-maker" cells, placed in the muscularis propria of the GI tract, responsible for regulation of peristalsis. They go through "gain of function" mutation of KIT protooncogene responsible for activation of protein CD117, a transmembrane tyrosine kinase growth factor receptor, which leads to proliferation of tumor cells and inhibition of their apoptotic death. Positive immunoreactivity for CD117 is the main parameter which separates GISTs from other mesenchymal tumors of the Gl tract and the basis for targeted therapy with tyrosine kinase inhibitors (TKI) (imatinib Gleevec, sunitinib - Sutent) $[1,2]$.

GIST may appear throughout the entire length of the Gl tract, but the most common site of origin is stomach $(60-70 \%)$, followed by small intestine (20-25\%), and rarely colon, rectum, esophagus or appendix. Primary localization is closely related to the clinical manifestations and biological behavior of the tumor. It has been shown that even small GIST of the small intestine is far more likely to grow progressively and

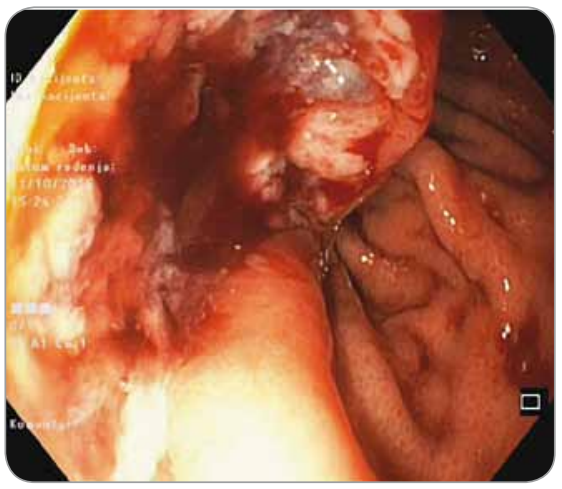

Fig. 1. Endoscopic appearance of gastrointestinal stromal tumor. disseminate, compared to gastric GIST bigger in size, which more frequently has indolent clinical course and is diagnosed accidentally [2].

It is estimated that only $10-30 \%$ of GISTs exhibit their malignancy, where the main predictors of such behavior are the number of mitosis and the size of tumor. In contrast to other soft tissue tumors, most metastasis of GIST are liver metastasis or peritoneal seeding, while lymph node involvement is rare, occurring in only $0-8 \%$ cases $[2,3]$.

Since GIST develops as a submucosal and intramural process, it takes some time for it to become clinically expressed, while $10-30 \%$ of patients may be completely asymptomatic. When symptoms do appear, the most common are hematemesis or melena in $40-65 \%$ of patients. Bleeding occurs because of pressure necrosis and ulceration of the overlying mucosa with resultant hemorrhage from disrupted vessels. Obstructive symptoms are usually site-specific and can result from intraluminal growth of an endophytic tumor or from extraluminal compression from an exophytic lesion. Other common symptoms include abdominal pain, anemia, anorexia, nausea, vomiting, weight loss and dysphagia $[2,4,5]$.
The "gold standard" for therapy in GIST is complete surgical resection of localized tumor; it offers the only chance for cure from GIST. Even after complete resection of primary GIST, at least $50 \%$ of patients develop recurrence or metastasis in the first 2 years. Locally recurrent tumors are not usually suitable for complete resection because of peritoneal implantation. Survival after complete surgical resection ranges from 48 to $80 \%$ at 5 years. If resection is not complete, only $9 \%$ of patients survive for an average of 12 months. Imatinib mesylate is the first effective drug with response rate of $54 \%$ in the treatment of metastatic GIST; nowadays, it is the drug of choice for unresectable, metastatic, or recurrent GISTs $[2,4]$.

\section{Case report}

A 69-year-old woman was referred to our surgical department due to the Gl stromal tumor which was found 2 months earlier on upper endoscopy (Fig. 1). Initial symptoms included epigastric pain, dysphagia and rapid weight loss. Computed tomography scan showed multiple bilobar liver metastases and a large $8.2 \times 11.1 \mathrm{~cm}$ tumor located in esophago-gastric junction (Fig. 2). Car-

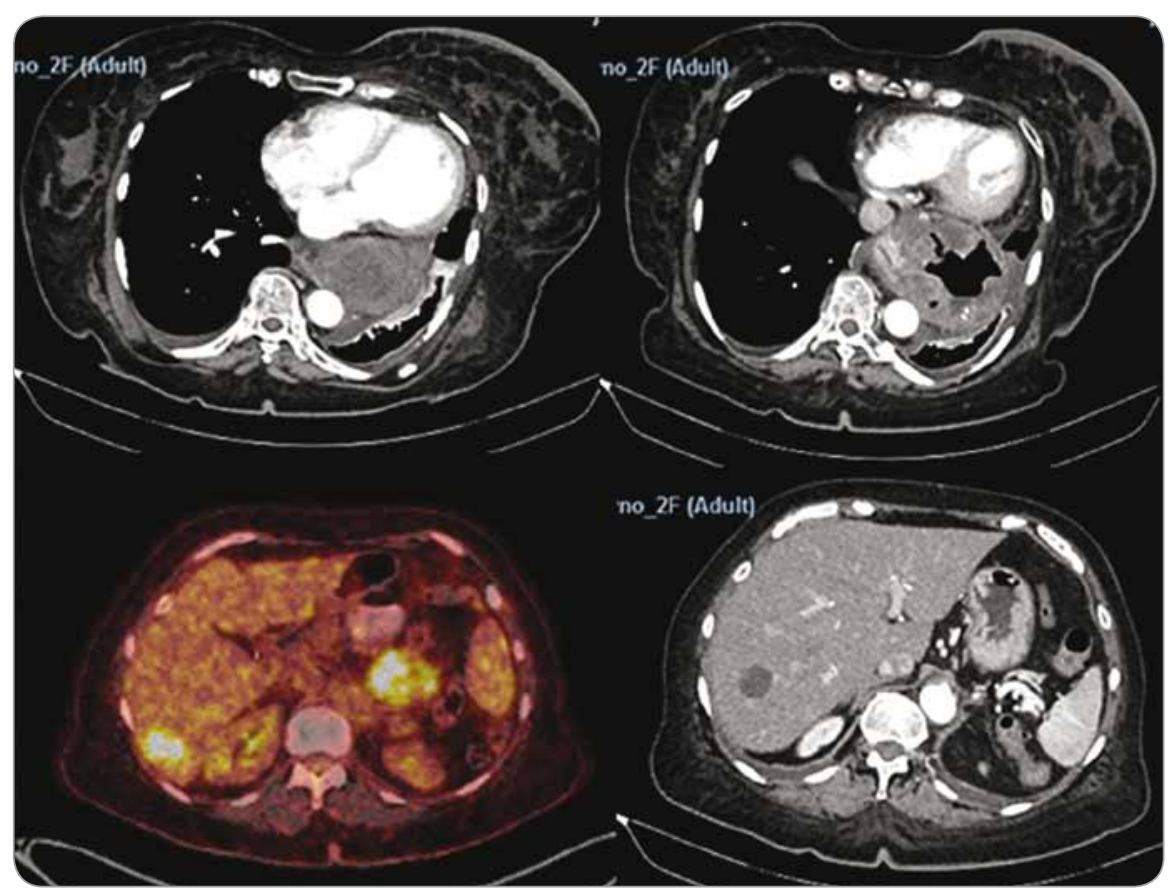

Fig. 2. Positron emission tomography scan showing stomach gastrointestinal stromal tumor and liver metastases. 
dia and most of the fundus were displaced intrathoracally due to the large sliding hiatal hernia. The tumor was considered inoperable initially, and chemotherapy with imatinib was started. After four cycles of chemotherapy, patient developed mycrocitic anemia which could not be managed by blood transfusions. Endoscopy confirmed diffuse bleeding from the tumor. Considering this, we indicated urgent surgical exploration and planned a palliative gastric resectional procedure. Intraoperatively, there was a large hiatal hernia and an expansive tumor at the gastroesophageal junction which infiltrated the edges of hiatal orifice, cardia and upper part of fundus (Fig. 3a). After the partial resection of the diaphragm, we performed proximal esophago-gastrectomy with esophagogastric anastomosis on the middle part of stomach corpus (Fig. 3b). Surprisingly, 12 months after the treatment, the patient was still alive and there were no signs of local (gastric) tumor recurrence while hepatic metastases remained stable under imatinib therapy.

\section{Discussion}

GISTs are the most common mesenchymal tumors of the Gl tract and account for about $1-3 \%$ of all Gl malignancies. In total, $60-70 \%$ of GISTs are gastric neoplasms, from which $15 \%$ affect cardia and fundus, $70 \%$ body and $15 \%$ antrum. Small intestine is the second most common site of origin in about $20-30 \%$ of cases, mainly in jejuno-ileum. Other literature supports the fact that tumors at other primary sites are very rare, 5-15\% in colon and rectum, and less than $5 \%$ in the esophagus. Several cases of other locations have also been reported $[6,7]$.

Currently available literature presents only few case reports of GIST in the esophago-gastric junction, while others classify them among gastric or esophageal GISTs without precise anatomical localization. Concurrent involvement of stomach and esophagus, as presented in our case, is extremely rare. One paper gives an overview of seven case reports of GIST in hiatal hernia, and several ones are related to spontaneous bleeding of the gastric GIST, either caused by spontaneous rupture of giant gastric GIST

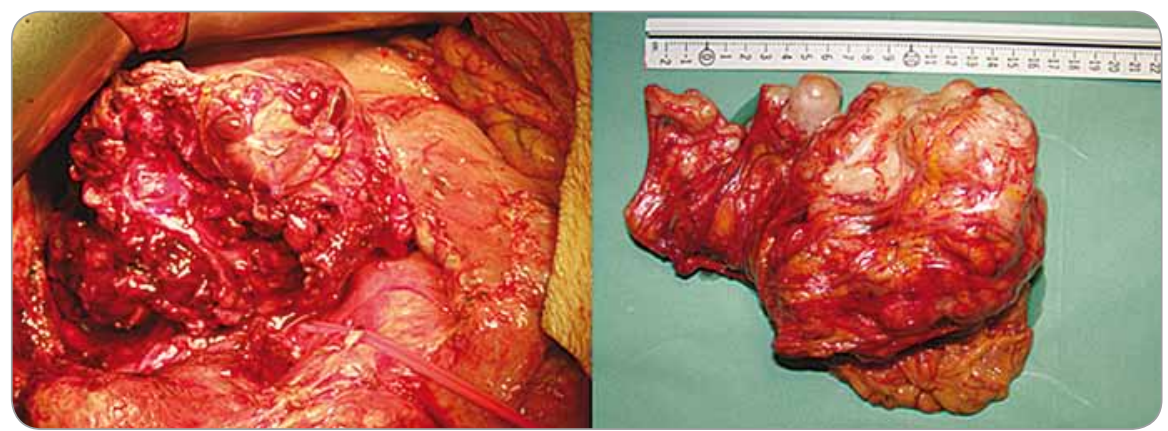

Fig. 3A. Intraoperative photo showing gastrointestinal stromal tumor and diaphragmatic crus. 3B. Specimen after proximal gastrectomy showing "en-block" tumor and esophago-gastric junction.

or intratumoral bleeding due to necrosis. Symptoms of lumen obstruction due to large extraluminal expansive process have also been reported, as GISTs may vary in size from 1 to $40 \mathrm{~cm}$ in diameter. Our case report sums up all of those unconventional presentations of GIST and puts them into context of clinical emergency in an inoperable disease, as that is the point in which subject of GIST treatment becomes a bit controversial $[8,9]$.

NCCN guidelines put surgery as the initial treatment for a localized and resectable disease. The goal should be complete resection with an intact pseudocapsule. Compared to other stomach malignancies, there is no indication for routine lymphadenectomy due to low frequency of lymph node involvement.

Speaking of advanced GIST, in the last few years, surgical treatment has gone through many improvements since primary chemotherapy and neoadjuvant therapy with TKI gave possibility to make locally advanced primary GIST resectable, allowing for less invasive procedures or promoting preservation of function.

TKI (imatinib, sunitinib, and regorafenib) target KIT and/or platelet-derived growth factor receptors and they are indicated for unresectable, metastatic or recurrent GISTs. With regards to adjuvant therapy, oncologists reserve imatinib for those patients who meet criteria for "high-risk" based on tumor size and mitotic index.

It is thought that surgery may have a limited positive impact on progression-free survival and overall survival in cases of good response to imatinib therapy, or those with limited focal progression. Thus, at present, surgery may be discussed with the patient, but not recommended based on a definitive proof of benefit. The case of our patient favors performing surgery even in stage IV disease with hepatic metastases as it turned out to be a good emergent and palliative procedure. Patient is alive 12 months after the procedure and stable under imatinib therapy without signs of recurrence. For patients who do not respond to imatinib therapy, surgery should not be offered, unless as a palliative intervention. In those cases, it is recommended to give sunitinib as the drug of second and regorafenib as the $3^{\text {rd }}$ line of choice [7,9]. Major causes of such drug resistance are additional mutations (primary or secondary) in the kinase domains of the KIT genes [10].

The primary location of GIST presented in our case is esophago-gastric junction. It is shown that gastric and esophageal GISTs have better prognosis than GISTs of non-gastric origin. One study concluded that in both gastric and non-gastric group, the size of tumor and mitotic activity were the most important prognostic factors related to progression-free survival. Risk of progression for GISTs larger than $10 \mathrm{~cm}$ with mitotic index less than $5 / 50$ high-power field is $10 \%$ for gastric and $34-57 \%$ for GISTs of other origin. For GISTs larger than $10 \mathrm{~cm}$ and mitotic index above 5/50 HPF, risk of progression is equally high (86\%) regardless of localization.

Even though some other papers gave opposed results regarding anatomic localization being a prognostic fac- 
tor for survival independent of tumor size, more of them represented thesis that patients with small intestinal GISTs had poorer outcomes than those with gastric tumors $[7,9]$. GISTs are 4 times more likely to recur if the primary site is the intestine compared to stomach. These data should be considered when evaluating success of surgical resection of recurrent tumors since the primary site could potentially condition the ultimate outcome in form of overall survival and recurrence-free survival [10-15].

\section{Conclusion}

Our case confirms that patients with locally advanced, stage IV disease with hepatic metastases may benefit from surgery in terms of prolonged survival and quality of life. We also showed that urgent surgery for GIST complications may not just be a life-saving surgery, but also a good palliation procedure and, as our case shows, it may be a beneficial R2 resection which allows normal feeding and prevents fatal consequences of tumor bleeding. Consequently, it affects overall survival and symptoms-free period. It must also be emphasized that this success would not be possible without posi- tive response on imatinib therapy which could have been facilitated with "debulking" effect of our surgery.

Hence, we consider that treatment options of stomach GIST, even in advanced stages, should be interpreted differently than other stomach malignancies considering different pathological and oncological nature of tumors. Multidisciplinary and individualized approach is mandatory as well as meticulous preand postoperative planning and adequate follow-up plan.

\section{References}

1. Al-Thani H, El-Menyar A, Rasul Kl et al. Clinical presentation, management and outcomes of gastrointestina stromal tumors. Int J Surg 2014; 12(10): 1127-1133. doi: 10.1016/j.ijsu.2014.08.351

2. Machishi H, Okada Y, Nagai M et al. A rare case of huge gastrointestinal stromal tumor (GIST) of the stomach ex tending into the posterior mediastinum. Dig Dis Sci 2002 47(7): 1492-1497.

3. Miettinen M, Lasota J. Gastrointestinal stromal tumors: review on morphology, molecular pathology, prognosis, and differential diagnosis. Arch Pathol Lab Med 2006; 130(10): 1466-1478. doi: 10.1043/1543-2165(2006)130. 4. Nishida T, Blay JY, Hirota S et al. The standard diagnosis, treatment, and follow-up of gastrointestinal stromal tumors based on guidelines. Gastric Cancer 2016; 19(1): 3-14. doi: 10.1007/s10120-015-0526-8.

5. Demetri GD, von Mehren M, Blanke CD et al. Efficacy and safety of imatinib mesylate in advanced gastrointestinal stromal tumors. N Engl J Med 2002; 347(7): 472-480. doi: 10.1056/NEJMoa020461.
6. Mullady DK, Tan BR. A multidisciplinary approach to the diagnosis and treatment of gastrointestinal stromal tumor. J Clin Gastroenterol 2013; 47(7): 578-585. doi: 10.1097/MCG.0b013e3182936c87.

7. Melo C, Canhoto C, Manata F et al. Surgical treatment of giant gist with acute gastrointestinal bleeding: Case report. Int J Surg Case Rep 2018; 53: 354-357. doi: 10.1016/j. ijscr.2018.11.021.

8. Liu Q, Kong F, Zhou J et al. Management of hemorrhage in gastrointestinal stromal tumors: a review. Cancer Manag Res 2018; 10: 735-743. doi: 10.2147/CMAR. S159689.

9. Ford SJ, Gronchi A. Indications for surgery in advanced/metastatic GIST. Eur J Cancer 2016; 63: 154-167. doi: 10.1016/j.ejca.2016.05.019.

10. Schwameis K, Fochtmann A, Schwameis M et al. Surgical treatment of GIST - an institutional experience of a high-volume center. Int J Surg 2013;11(9): 801-806. doi: 10.1016/j.ijsu.2013.08.016

11. Akahoshi K, Oya M, Koga T et al. Current clinical management of gastrointestinal stromal tumor. World J Gastroenterol 2018; 24(26): 2806-2817. doi: 10.3748/wjg.v24. i26.2806.

12. Fujisawa R, Akiyama Y, Iwaya T et al. Giant gastrointestinal stromal tumor of the mediastinum associated with an esophageal hiatal hernia and chest discomfort: a case report. Surg Case Rep 2018; 4(1): 144. doi: 10.1186/s40792018-0553-X

13. Mehta RM, Sudheer VO, John AK et al. Spontaneous rupture of giant gastric stromal tumor into gastric lumen. World J Surg Oncol 2005; 3(1): 11. doi: 10.1186/14777819-3-11

14. Včev A et al. Gastrointestinalni stromalni tumor (GIST). Med Vjesn 2003; 35(1-4): 55-58

15. Nishida T, Doi T, Naito Y. Tyrosine kinase inhibitors in the treatment of unresectable or metastatic gastrointestinal stromal tumors. Expert Opin Pharmacother 2014; 15(14): 1979-1989. doi: 10.1517/14656566.2014.937 707. 


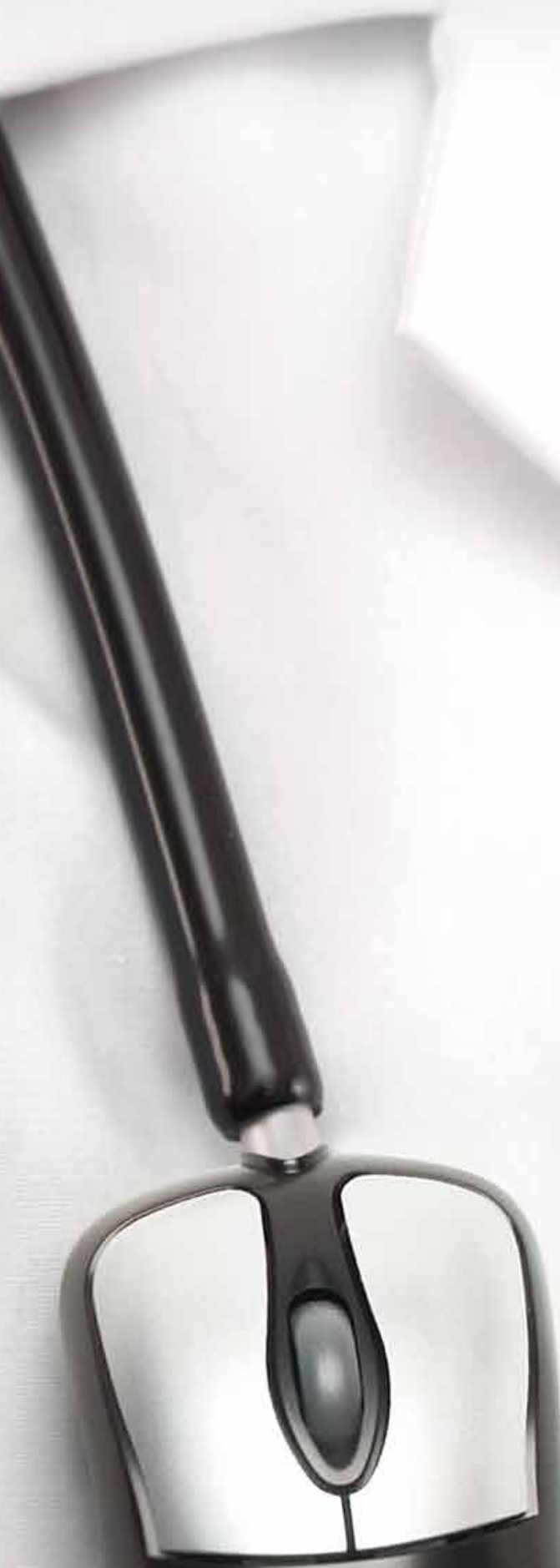

\section{Omnia ad sciendum necessaria INTRANET|C̈IS}

Užívejte si být uživatelem Intranetu ČIS. Stačí kliknout na www.cis-intranet.cz 